\title{
Possessing Nature
}




\section{STUDIES ON THE HISTORY OF SOCIETY AND CULTURE \\ Victoria E. Bonnell and Lynn Hunt, Editors}

1. Politics, Culture, and Class in the French Revolution, by Lynn Hunt

2. The People of Paris: An Essay in Popular Culture in the Eighteenth Century, by Daniel Roche

3. Pont-St-Pierre, 1398-1789: Lordship, Community, and Capitalism in Early Modern France, by Jonathan Dewald

4. The Wedding of the Dead: Ritual, Poetics, and Popular Culture in Transylvania, by Gail Kligman

5. Students, Professors, and the State in Tsarist Russia, by Samuel D. Kassow

6. The New Cultural History, edited by Lynn Hunt

7. Art Nouveau in Fin-de-Siècle France: Politics, Psychology, and Style, by Debora L. Silverman

8. Histories of a Plague Year: The Social and the Imaginary in Baroque Florence, by Giulia Calvi

9. Culture of the Future: The Proletkult Movement in Revolutionary Russia, by Lynn Mally

10. Bread and Authority in Russia, 1914-1921, by Lars T. Lih

11. Territories of Grace: Cultural Change in the Seventeenth-Century Diocese of Grenoble, by Keith P. Luria

12. Publishing and Cultural Politics in Revolutionary Paris, 1789-1810, by Carla Hesse

13. Limited Livelihoods: Gender and Class in Nineteenth-Century England, by Sonya O. Rose

14. Moral Communities: The Culture of Class Relations in the Russian Printing Industry, 1867-1907, by Mark Steinberg

15. Bolshevik Festivals, 1917-1920, by James von Geldern

16. Venice's Hidden Enemies: Italian Heretics in a Renaissance City, by John Martin

17. Wondrous in His Saints: Counter-Reformation Propaganda in Bavaria, by Philip M. Soergel

18. Private Lives and Public Affairs: The Causes Célèbres of Pre-Revolutionary France, by Sarah Maza

19. Hooliganism: Crime, Culture, and Power in St. Petersburg, 1900-1914, by Joan Neuberger

20. Possessing Nature: Museums, Collecting, and Scientific Culture in Early Modern Italy, by Paula Findlen 


\section{Possessing Nature Museums, Collecting, and Scientific Culture in Early Modern Italy}

\section{Paula Findlen}

UNIVERSITY OF CALIFORNIA PRESS Berkeley Los Angeles London 


\section{The publisher gratefully acknowledges the contribution provided by the General Endowment Fund of the Associates of the University of California Press}

University of California Press

Berkeley and Los Angeles, California

University of California Press

London, England

Copyright $@ 1994$ by The Regents of the University of California

First Paperback Printing 1996

\section{Library of Congress Cataloging-in-Publication Data}

Findlen, Paula.

Possessing nature : museums, collecting, and scientific culture in early modern Italy / Paula Findlen.

p. cm. - (Studies on the history of society and culture ; 20)

Includes bibliographical references and index.

ISBN: 978-0-520-20508-6

1. Science museums-Italy-History. 2. Science museums-Europe-

History. 3. Natural history museums-Italy-History. 4. Natural history museums-Europe-History. I. Title. II. Series. Q105.I8F56 1994

$508^{\prime} .074^{\prime} 45-\mathrm{dc} 20$

Printed in the United States of America

$$
\begin{array}{lll}
09 & 08 & 07
\end{array}
$$

$$
\begin{array}{llllll}
12 & 11 & 10 & 9 & 8 & 7
\end{array}
$$

The paper used in this publication is both acid-free and totally chlorine-free (TCF). It meets the minimum requirements of ANSI/NISO Z39.48-1992 (R 1997) 
To my great-grandmother Margaret Black Avery:

a museum in her own right 

The soul of man affects a kind of infinity in its objects. The affectations are always reaching after new pleasures, the desires carried forth after new possessions. . . the eye is never satisfied with seeing.

-JOHN SPENCER, DISCOURSE CONCERNING PRODIGIES (1665) 
